\title{
African Star Apple: Potentials and Application of Some Indigenous Species in Nigeria
}

\author{
${ }^{*}$ ADEKANMI, DG, ${ }^{2}$ OLOWOFOYEKU, AE \\ ${ }^{I}$ Department of Chemistry, Nigerian Defence Academy, Kaduna, Nigeria. \\ ${ }^{2}$ Pan African University of Life and Earth sciences Institute (including Health and Agriculture), University of Ibadan, Nigeria \\ *Corresponding Author Email: dangbemiga@gmail.com
}

\begin{abstract}
Many research in food and pharmaceuticals are focused on the use of materials as close to nature as possible to limit exposure to harmful synthetic substances. Alternatives are being sought for popular plant based materials leading to increased attention to underutilized plants and creating ripple effects in agriculture, agribusiness, health and pharmaceuticals. A plant that is attaining prominence in Nigeria and in the rain forests of West Africa is the African Star Apple. The plant is best known for the juicy pulp of its fruit but the traditional therapeutic use of parts of the plants are also common. Some authors have investigated and documented some benefits obtained from its leaves, stem, root and fruits. This paper focuses on the features, food and pharmaceutical potentials of the oil, flour, extracts and gum form the African Star Apple. Its fruit is rich in minerals and antioxidant while extracts from various parts of the plant have good antimicrobial and antifungal properties. The review also reveals that the African Star Apple has many potential food and pharmaceutical applications that are yet to be explored.
\end{abstract}

\section{DOI: https://dx.doi.org/10.4314/jasem.v24i8.1}

Copyright: Copyright (C) 2020 Adekanmi and Olowofoyeku. This is an open access article distributed under the Creative Commons Attribution License (CCL), which permits unrestricted use, distribution, and reproduction in any medium, provided the original work is properly cited.

Dates: Received: 16 May 2020; Revised: 29 June 2020; Accepted: 07 July 2020

Keywords: African Star Apple, Chrysophyllum albidum, Phytochemicals, Gum, Extracts.

Plants have been the source of many materials used in clothing, food and pharmaceuticals. They provide natural alternatives to synthetic compounds resulting in increased attention for underutilized plants. One of such is the African Star Apple (Chrysophyllum albidum). Over the years, many extracts and hydrocolloids of plant origin have proven effective in food and pharmaceutical applications. With most of these plants having historic and traditional application for the treatment of ailments and conditions, others have been used in formulation of drinks, concoctions and some as food constituents (Amaechi, 2009).

This review highlights prominent work done on the potentials of African Star Apple (Chrysophyllum albidum) which is a distinct member of the family Sapotaceae in Nigeria. Review: The African Star Apple is from the family Sapotaceae and its botanical name is Chrysophyllum albidum. The family Sapotaceae is of the order Ericales. The family comprises seventy (70) genera and eight hundred (800) species. Each of the specie produces milky latex (Gill, 1988). Twenty-three (23) genera and over three hundred (300) species are found in West Africa including Chrysophyllum, Kanton, Mimusops, Breviea, Delipdora and Manikara (Gill, 1988). Nigeria has seven (7) of the species including albidum and africanum. The name Chrysophyllum is coined from the Greek word for "Golden leaf" which depicts the colour of the leaves of some of its species.

The African Star Apple fruit has gained popularity and is widely consumed because of its fleshy pulp but the seeds are discard (Adisa et al., 2000). Its common name in Nigeria include cherry, agbalumo (Yoruba), udara (Ibo) and ehya (Igala) (Akubor, Yusuf, and Obiegunam, 2013). The Hausas fondly call it Agwaluma and in Ghana it is known as Alasa. In neighbouring country, Benin the southerners have variant names for the fruit in their dialects. The names include azongogwe or azonbobwe, Fon or Goun, azonvivo or azonvovwe and azonbebi (Dah-Dovonon, 2000). In Nigeria, the fruits emerge on the tree in the month of July as dark green balls and turn yellow or orange as it ripens. Locals believe that the pulp will be sweet if the colour of the fruit is yellow and bitter if the colour is a mixture of green and yellow. The ones with orange colour are most preferred (Asare et al., 2015). The ripe fruit can be found in the market between December to March. Yearly, a huge amount of the fruit is lost due to deterioration during gathering, transportation and storage. Amusa et al. (2003) confirmed that the deterioration of the pulp begins after about five days under ambient conditions and also investigated the use of the fruit as drinks and jams to mitigate the yearly loss. 
Botany: The plant, commonly found in Central, Eastern and West Africa is about 8 to 36 metres tall. It is commonly propagated by its seedlings, wildings and by direct sowing. African Star Apple tree has evergreen leaves which are elliptic, slightly leathery and alternate. The fruit usually has five central radially-arranged seeds. When the fruit is cut transversely, the seeds section appears as a star hence the name Star Apple (Edem, Eka, and Ifon, 1984). The specie Chrysophyllum africanum is widely distributed in West and Central Africa and usually found on riverside, in forest and villages. Its wood has fine to medium grain texture (Nwadinigwe, 1982). Another member of the family Chrysophyllum oliviforme commonly found in Florida (USA) grows up to 14 meters and can spread to 8 meters across. Possessing 4-inch long glossy dark green leaves, satinleaf as it is popularly called, remains evergreen like the Chysophyllum albidum and Chrysophyllum africanum. Its fruits are however long and oval (Gilman, et al., 2018).

Nutritional benefits:African Star apple fruit has long been an available source of carbohydrates, proteins, fats and oils (Okigbo, 1978). Authors Adisa et al. (2000) and Amusa, Ashaya, and Oladapo, (2005) investigated the nutritional benefits of the African Star Apple fruit and found it to be rich in vitamins and iron. The pectin, vitamin $\mathrm{C}$ and polyphenols rich plant has potential for detoxification and reducing sugar absorption (Manganaris et al., 2014). Ureigho and Ekeke (2010) and Okwu et al. (2018) studied the organoleptic variation of species of African Star Apple fruits in contrast with their proximate parameters. The fruits had mean values of $73.33,2.64,3.61$ and $16.99 \%$ for the moisture, ash, fibre and protein contents respectively. The fruit is abundant in vitamins $(25.03$ $\mathrm{mg} / 100 \mathrm{~g}, 10.74 \mu / 100 \mathrm{~g}, 0.15 \mu / 100 \mathrm{~g}$ and $0.04 \mu / 100 \mathrm{~g}$ for Vitamin C, Vitamin A, Vitamin B1 and Vitamin B2 respectively) and the vitamin content remains essentially the same in sweet and sour fruits. The authors observed that the sweeter fruits have lower amount of carbohydrates and crude ash while the sour fruits are rich in carbohydrates and crude ash. In addition, both the sweet and sour fruits have similar values for lipids and crude fibre. Studies by Oloyede and Oloyede (2014) on the antioxidant and food value of Chrysophyllum albidum showed the plant contains some phenols, flavonoids, anthocyanin and proanthocyanidin. The anti-nutrient profile showed that the sour fruits contain a significant amount of phylate, oxalate, flavonoids, phenols and tannins (Okwu, Osazuwa, and Igberaese, 2018). A report by Adeleye et al. (2016) also confirmed the presence of cardiac glycoside which makes the fruit a good remedy for congestive heart failure (Aboaba, Smith, and Olide, 2006). Comprehensive examination by Ibrahim et al. (2017) revealed that the seed shell pericarp has more alkaloids $(25.80 \%)$, tannins $(10.19 \%)$ and vitamin C $(0.12 \mathrm{mg} / 100 \mathrm{~g})$ while the skin has more saponins $(0.41 \%)$ and flavonoid $(17.23 \%)$ content. The pulp has the lowest concentration of the phytochemicals quantified. The seed shell pericarp has higher crude protein $(8.66 \%)$ and fat $(8.07 \%)$ content while the fruit pulp has more carbohydrates $(66.45 \%)$ and the fruit skin is copious in crude fibre (15.57\%). Christopher and Dosunmu (2011), Ewanshilha et al. (2011) and Ibrahim et al. (2017) reported similar carbohydrate and crude fat values for the fruit. The flavonoids found in the fruit scavenge free radicals, alkaloids are beneficial for their anti-inflammatory properties (Kuraset al., 2009) and saponins possess hypocholesterolemic property by their ability to form insoluble complexes with cholesterol significantly reducing its absorption (Aletor, 1993).

Asare et al. (2015) compared the mineral composition of the peel and pulp of the African Star Apple fruit and found the peel to be richer than the pulp for all the elements determined except for potassium and sodium. The authors recorded exact values for sodium in the pulp and peel $(2210 \mathrm{mg} / \mathrm{Kg})$ while the pulp was copious in potassium $(30105 \mathrm{mg} / \mathrm{Kg})$. The lactic acid and acetic acid content of the pulp (2.9 and 1.9\% respectively) were higher than that of the peel $(0.88$ and $0.59 \%$ respectively). The pulp was abundant in protein and carbohydrate content (4.1 and 60.1\%). Iheanyichukwu et al. (2017) determined the mineral composition of the leaves and pulp of the specie Chysophyllum africanum. Its leaves were richer in zinc and copper than the pulp (1.87 and $0.88 \mathrm{mg} / 100 \mathrm{~g}$; 0.48 and $0.29 \mathrm{mg} / 100 \mathrm{~g}$ respectively) but for other minerals determined the pulp was found to be significantly higher especially in potassium, calcium and magnesium $(1436.38,185.49$ and $82.71 \mathrm{mg} / 100 \mathrm{~g})$. The leaves were also richer in vitamins for all the parameters determined (Ascorbic acid 28.34, Thiamine 13.32, Riboflavin 0.54, Pyridoxine 56.82, Nicotinamin 0.02 and Cyanocobalamin $0.05 \mathrm{mg} / \mathrm{kg}$ ). The results by Asare et al. (2015) and Iheanyichukwu et al. (2017) imply the fruit is a remedy in alleviating heart related disease and stroke being a rich source of potassium. Bello and Henry (2015) studied the effects of storage on the proximate composition of Chrysophyllum albidum under ambient conditions and reported an increase in moisture content and crude fibre in the pulp after 5 days from 36.45 to $46.69 \%$ and 2.54 to $2.89 \%$ respectively while the crude protein and energy dropped after the same number of days from 6.06 to $5.73 \%$ and 313.49 to $278.93 \%$. The energy content of the skin dropped from 305.61 to $297.29 \%$ but increased in the seed (310.64 to $321.57 \%$ ). The 
phlyate content of the pulp and skin increased ( 0.05 to 0.08 and 0.02 to $0.05 \mathrm{mg} / 100 \mathrm{~g}$ respectively) but a decrease was recorded for the seed $(0.71$ to 0.57 $\mathrm{mg} / 100 \mathrm{~g}$ ) after 5 days of storage. This results corroborates the findings of Adeboyejo et al. (2019) and suggest that fruits stored at ambient conditions for long loose nutritive value and become softer increasing their susceptibility to biodegradation. Oladimeji (2019) quantified the nutrients lost through oven air drying and freeze drying as methods of preserving the fruit. The fat and protein content were lowest after oven drying (3.56 and $5.44 \%$ ) but the carbohydrate content increased significantly in the oven dried and freeze dried fruits but was higher in the first $(75.46 \%)$. He also observed that the edible part of the fruit lost $19 \%$ its Vitamin C content through oven drying and $4 \%$ through freeze drying making freeze drying a better method for preserving the fruit.

Table 1: Minimum inhibitory concentration of various extracts of the African Star Apple reported by some authors. [Idowu et al., (2016); b: Oputah et al. (2016); c: Adeleye et al. (2016)]

\begin{tabular}{|c|c|c|c|c|c|}
\hline & $\begin{array}{l}\text { Crude ethanolic } \\
\text { extract from } \\
\text { bark (mg/mL) }\end{array}$ & $\begin{array}{l}\text { Aqueous } \\
\text { fraction from } \\
\text { bark (mg/mL) }\end{array}$ & $\begin{array}{l}\text { Ethanolic extract } \\
\text { cotyledon } \\
\text { (mg/mL) }\end{array}$ & $\begin{array}{l}\text { Aqueous } \\
\text { extract of fruit } \\
\text { (mg/mL) }\end{array}$ & $\begin{array}{c}\text { Ethanolic } \\
\text { extract of fruit } \\
(\mathrm{mg} / \mathrm{mL})\end{array}$ \\
\hline E. coli & 0.625 & 1.250 & 6.50 & 25 & 50 \\
\hline S. aureus & 0.625 & 1.250 & - & 25 & 50 \\
\hline P. aeruginosa & 1.250 & 1.250 & 50 & - & - \\
\hline B. subtilis & 0.625 & 1.250 & - & - & - \\
\hline Proteus vulgaris & - & - & 12.50 & - & - \\
\hline
\end{tabular}

Extracts: The therapeutic potentials of medicinal plants lie in the type and concentration of bioactive substances in them. These bioactive substances are also called phytochemicals. These compounds are the reason for many plant based medicines (Iwu, Duncan, and Okunji, 1999). They provide the blueprint for the development of drugs and are also used for treatment of ailments (Asaolu, 2003). According to Okoli and Okere (2010), the extracts of the seeds and root of African Star Apple have anti-inflammatory, antidiarrheal and anti-hemorrhoidal qualities thus their use in home remedies and herbal treatments of certain diseases. Adeleye et al. (2016) carried out a comparative study on the extraction of the phytochemicals from Chrysophyllum albidum fruit. Phytochemicals were extracted from the powdered fruit with distilled water and methanol for five days. The phytochemicals were thereafter recovered by filtering the solution and allowing the solvent in the filtrate to evaporate. The phytochemical tests revealed the presence of flavonoids, alkaloids, tanins, steroids, anthraquinone and cardiac glycoside. The antimicrobial properties of the extracts were assessed on Escherichia coli, Staphylococcus aureus, Klebsiella pneumonia and Candida albicans. The inhibition zones of the extracts were determined at various concentration $(25,50$ and $100 \mathrm{mg} / \mathrm{mL})$. The aqueous extracts proved more effective at a minimum inhibitory concentration of $25 \mathrm{mg} / \mathrm{mL}$ whereas the minimum inhibitory concentration of methanolic extract was $50 \mathrm{mg} / \mathrm{mL}$. The extracts of the seed cotyledons was successful in the treatment of $C$. albicans while the root extracts inhibited Pseudomonas aeruginosa, Escherichia coli, Staphylococcus aureus, C. tetani, Bacillus subtilis, and Candida albicans, These results corroborate the findings of Adewusi (1997) who reported that the latex of African Star Apple had antimicrobial potentials. Oputah et al. (2016) examined the ethanolic extracts of the cotyledons and seed coat. While the seed coat contained only carbohydrates, cardiac glycosides and fatty acids, the cotyledons was rich in the above, saponins, flavonoids, terpenoids and quinones. In the comparative study of the antibacterial activity of the extract, Gentamicin was used as the control. Pseudomonas aeruginosa was resistant to the control but susceptible to the extracts with inhibitory zones of 13 and $18 \mathrm{~mm}$ for the cotyledon and seed coat at minimum inhibitory concentrations of 50 and 6.25 $\mathrm{mg} / \mathrm{mL}$ respectively (Table 1 ). Probiotics such as Lactobacillus lactis and Lactobacillus plantarum were isolated from African Star Apple fruits and their antimicrobial activity assessed on Escherichia coli, Bacillus subtilis, Staphylococcus aureus, Klebsiella $s p$. and Proteus sp. The mean zones of inhibition observed for the probiotics were $1.87 \mathrm{~mm}$ and 18.96 mm signifying biopreservative qualities (Lawal et al., 2016).

Ibrahim et al. (2017) compiled a detailed list of compounds extracted from the pulp, seed shell pericarp and skin using n-haxane. While five of the six constituent compounds of the seed shell pericarp are fatty acids, the ones with hypolipidemic and hypocholesterolemic properties are Cis-vaccenic acid and n-Hexadecanoic acid respectively. The pulp was found to contain more compounds with antioxidant, antifungal, antibacterial and Hypocholesterolemic properties most of which are aromatic compounds or alkyl ester. These compounds include Benzene (1pentylheptyl), Benzene(1-butyloctyl), Benzene(1propylnonyl), Methyl tetradecanoate, Tetradecane, Hexadecanoic acid, methyl ester, Hexadecanoic acid ethyl ester, 9,12-Octadecadienoic acid-methyl ester 
and 11-Octadecenoic acid, methyl ester. The fruit skin also contains some of the therapeutic compounds found in the pulp such as 9, 12-Octadecadienoic acidmethyl ester, Methyl tetradecanoate and others: Eicosane and Octadecanoic acid methyl ester. Iheanyichukwu et al. (2017) analyzed the Chysophyllum africanum pulp and found it to be richer in phenols, flavonoids and 2, 2- diphenyl-1picrylhydrazyl $(2305.83 \mathrm{mg}$ of Gallic Acid Equivalents, $308.89 \mathrm{mg}$ of Quercetin Equivalents $/ 100 \mathrm{~g}, \quad 65.93 \%$ respectively) than the leaves which had more Ascorbic acid (72.60 mg Quercetin Equivalents/100g). Akubor et al. (2013) investigated the proximate and functional properties of African Star Apple kernel seed flour in comparison with wheat flour and proposed the possibility of incorporating it in food formulations. An attempt to replicate these by replacing maize with the flour of the seeds in Clarias graiepinus fish feed had negative impact on their growth (Jimoh and Oladiji, 2004). Ajayi and Ifedi (2015) incorporated Chrysophyllum albidum seed flour into the dietary formulation of albino rats to determine its toxicity. For some of the test animals, there was total replacement of wheat with the seed flour. This replacement led to increase in proximate composition of the compounded feed. After the eight weeks of the experiment, none of the rats suffered toxic reaction rather they experience weight gain when compared with the animals fed with wheat flour diet. Blood chemistry, heamatological test and histopathological examinations reveal no adverse effect on the test subjects. Oil yield is dependent on factors such as specie of the plant, its genes, soil condition, and climate among others. Efficient processing techniques such as moderate exposure to sunlight or heat also increase oil yield (Antony, Smart, and Lee, 2011). Anang et al. (2019) characterized the oil extracted from African Star Apple seeds. The oil yield was quite low (11.6\%) which was comparable to that obtained by Adebayor (2012) and Umaru et al. (2015). The values reported for parameters such as the acid value, Iodine value, saponification value and specific gravity vary from author to author as shown in Table 2. Although the IR spectrum of the oil had similar $\mathrm{C}=\mathrm{O}$ absorption with that obtained from Rosemary and Chamomile the low yield African Star Apple seeds limits it viability as source of oil (Anang et al., 2019, Anwer et al., 2015).

Table 2: Variation in African Star Apple seed oil parameters determined by various authors

\begin{tabular}{llllll}
\hline Parameter & $\begin{array}{l}\text { Anang } \text { et al. } \\
(2019)\end{array}$ & $\begin{array}{l}\text { Adebayo et al } \\
(2012)\end{array}$ & $\begin{array}{l}\text { Ominyi and } \\
\text { Ominyi (2016) }\end{array}$ & $\begin{array}{l}\text { Umaru et al } \\
(2015)\end{array}$ & $\begin{array}{l}\text { Omeje } \text { et al. } \\
(2018)\end{array}$ \\
\hline $\begin{array}{l}\text { Acid value } \\
(\mathrm{mg} / \mathrm{KOH} / \mathrm{g})\end{array}$ & 7.72 & 4.50 & 19.70 & -- & 17.41 \\
$\begin{array}{l}\text { Saponification } \\
\text { value }(\mathrm{mg} / \mathrm{KOH} / \mathrm{g})\end{array}$ & 200 & 199.50 & 90.71 & 228.4 & 236.341 \\
$\begin{array}{l}\text { Free fatty acid } \\
(\mathrm{mg} / \mathrm{KOH} / \mathrm{g})\end{array}$ & 3.16 & 2.25 & 9.90 & -- & $8.75(\%)$ \\
\hline
\end{tabular}

African Star Apple gum: Exudate gums are usually collected raw and need to be purified before application. Some of the foreign objects can be removed by hand picking while those embedded within the matrix of the gum need to be extracted by first dissolving the gum and separating it using the appropriate solvent. When gums are obtained from other sources like seeds, fruits and other plants parts, these part may need to be crushed and dispersed in solution to extract the gum. Then the gum is recovered from the solution using an organic solvent. The common solvents are methanol, ethanol, propanol or acetone. Eichie et al. (2015) precipitated the African Star Apple gum by treating the solution of the pulp with 1:1 methanol. The gum was thereafter dried and ground to fine powder for storage. Okoye and Ndiwe (2016) compared the quantity of gum obtained from the solution of the exocarp and mesocarp and that of the mesocarp alone while also comparing the effect of solvent used on the amount of gum precipitated from both the exocarp and mesocarp and mesocarp alone. The yield of the gum from the exocarp and mesocarp together was lower to that obtained from the mesocarp alone. Ethanol was the preferred solvent as it gave more yield. Gum obtained through acetone was observed to be darker and it was attributed to oxidation during the drying process. Eichie et al. (2015) reported the solubility profile of the gum which was determined in various solvent at various temperature. The media use included $0.1 \mathrm{~N} \mathrm{HCl}, 0.1 \mathrm{~N} \mathrm{NaOH}$, acetone, chloroform, methanol, ethanol and water. The gum was only soluble in water even at $90^{\circ} \mathrm{C}$. The authors also reported that the bulk density of the gum was 0.7 $\mathrm{g} / \mathrm{ml}$ and its swelling capacity was 2.0 and observed that the viscosity of the gum at $7.5 \%$ was five time that of A. Senegal. Bakre and Akinsanya (2019) observed that the particle density and bulk density of the African Star Apple gum were 1.3728 and 0.3575 respectively (Table 3). They also reported the gum to be slightly acidic (6.5) and from the angle of repose $\left(29.29^{\circ}\right)$ the gum had better flowability than Taragacanth gum in tablet formulation. These properties are similar to those of the seed gum reported by Ologunagba et al. (2017). The seed gum tested positive for carbohydrates (Oladimeji 2019; Ologunagba et al., 2017) and negative for alkaloids, flavonoids and 
Saponins (Ologunagba et al., 2017). Bakre and Akinsanya (2019) studied the changes in the physicochemical and compressional characteristics of Chrysophyllum albidum gum after crosslinking with calcium chloride. Higher densities were observed for the cross-linked gum indicating slower onset of plastic deformation. In the study by the authors, the IR spectrum of African Star Apple gum has a broad absorption at $3291 \mathrm{~cm}^{-1}$ due to hydrogen bonded $-\mathrm{OH}$ groups and strong sharp peaks at $1729 \mathrm{~cm}^{-1}$ for $\mathrm{C}=\mathrm{O}$ stretch. The cross-linking of Calcium Chloride to the gum led to the disappearance of some peaks and strengthening of others. A slight shift was noticed in the hydrogen bonded $-\mathrm{OH}$ band from $3291 \mathrm{~cm}^{-1}$ to $3272 \mathrm{~cm}^{-1}$ which was attributed to reduction in the degree of hydrogen bonding. The $\mathrm{C}=\mathrm{O}$ peak remained intact at $1729 \mathrm{~cm}^{-1}$ with the addition of a new peak at $1617 \mathrm{~cm}^{-1}$ attributed to the formation of $\mathrm{Ca}=\mathrm{O}$. The decomposition temperature observed from the DSC curve of native Chrysophyllum albidum gum and that cross-linked with Calcium Chloride are $258^{\circ} \mathrm{C}$ and $240^{\circ} \mathrm{C}$ respectively indicating no permanent change occurred in the interaction between the gum and the crosslinking agent.

Table 3: Physicochemical properties of African Star Apple gum

\begin{tabular}{|c|c|c|c|c|c|c|c|}
\hline Parameter & $\begin{array}{l}\text { Chrysophyllum } \\
\text { albidum seed } \\
\text { gum }\end{array}$ & $\begin{array}{l}\text { Chrysophyllum } \\
\text { albidum gum }\end{array}$ & $\begin{array}{l}\text { Chrysophyllum } \\
\text { albidum seed } \\
\text { Flour }\end{array}$ & $\begin{array}{l}\text { Fresh } \\
\text { Chrysophyllum } \\
\text { albidum Pulp }\end{array}$ & $\begin{array}{l}\text { Fresh } \\
\text { Chrysophyllum } \\
\text { albidum kemel } \\
\text { Flour }^{4}\end{array}$ & $\begin{array}{l}\text { Fresh } \\
\text { Chrysophnllum } \\
\text { albidum Pulp }\end{array}$ & $\begin{array}{l}\text { Fresh } \\
\text { Chrysophyllum } \\
\text { albidum seed }\end{array}$ \\
\hline Moisture (\%) & 11.73 & 66.67 & 9.93 & 35.0 & 9.0 & 69 & 8.12 \\
\hline Swelling index (\%) & 3.19 & 23.81 & -- & - & - & - & - \\
\hline Hausner's ratio & 1.08 & 1.2274 & - & - & - & - & - \\
\hline Angle of repose $\left({ }^{\circ}\right)$ & 30.0 & 29.29 & - & - & - & - & - \\
\hline $\operatorname{Ash}(\%)$ & 0.50 & & 2.32 & 4.0 & 3.8 & 3.1 & 3.86 \\
\hline Emulsion capacity & - & 17.50 & - & - & - & - & - \\
\hline Bulk density $\left(\mathrm{g} / \mathrm{cm}^{3}\right)$ & 0.61 & 0.3575 & - & - & - & - & - \\
\hline Tapped density, $\mathrm{g} / \mathrm{cm}^{3}$ & 0.66 & 0.4388 & - & - & - & - & - \\
\hline $\mathrm{pH}$ & 6.0 & 6.5 & $\ldots$ & - & - & -- & - \\
\hline
\end{tabular}

Applications: In the southern parts of Nigeria, ethnomedical use of parts of the African Star Apple plant include the treatment of sprains, bruises, and wounds (Olorunnisola, 2008). Sayyar et al. (2009) noted that extracts from the seed and root of Chrysophyllum albidum arrested bleeding from fresh wounds and enhanced healing by inhibiting the growth of dangerous wound microbes. According to Mbagwu et al. (2013), ripe fruits of Chrysophyllum canito is consumed to absolve laryngitis due to its mucilaginous content and is effective in the treatment of diabetes mellitus. Madufor et al. (2013) evaluated the extent of corrosion of aluminum in $0.1 \mathrm{M} \mathrm{H}_{2} \mathrm{SO}_{4}$ through weight loss and thermogravimetric techniques while using the Chrysophyllum albidum fruit extracts as inhibitor. The authors established that the fruit extracts had good corrosion inhibitory properties in acid environment due to its phytochemical constituents which adsorbed on the surface of the aluminum. The inhibitory efficiency of the extract also increased with increased concentration of the extract used and decrease in temperature. The potentials of the gum extracted from the seed of the African Star Apple fruit was investigated by Ologunagba et al. (2017). The authors found the seed gum to be effective as a binder in tablet formulation at $10 \% \mathrm{w} / \mathrm{w}$ which was comparable to that obtained for Accacia gum at the same concentration. A similar study by Okoye and Ndiwe (2016) compared the performance of the pulp gum and cashew gum as binder on ciprofloxacin tablets. The study revealed that the gums are viable binders in pharmaceutical applications but the mechanical properties of the tablets were only comparable at $6 \%$ and $2 \%$ concentration respectively.

Conclusion: Despite the food and pharmaceutical values of the African Star Apple revealed in the literatures, it is yet to find prominence in industrial application. This is due to lack of comprehensive studies on the characterization, stability and derivatization of its gum and extracts for improved performance. The plant present a viable source of gum, antioxidants and minerals which could be alternatives to popular constituents in food and drug formulation.

\section{REFERENCES}

Aboaba, O., Smith, S., and Olide, F. O. (2006). Antimicrobial effect of Edible plant Extract on Escherichia.Coli, 0157:H7. Pakistan. Jurnal of Nutrition, 5(4), 325-327.

Adebayo, S. E., Orhevba, B. A., Adeoye, P. A., Musa, J. J., and Fase, O. J. (2012). Solvent extraction and characterization of oil from african star apple (Chrysophyllum albidum) seeds. Academic Research International, 3(2), 178-183.

Adebayor, S. E. ((2012)). Solvent extraction and characterization of oil from african star apple 
(Chrysophyllum albidum) seeds. Academic Research International, 3(2).

Adeboyejo, F. O., Oguntoye, M. A., and Awe, O. E. (2019). Phytochemical components of beverages from African Star Apple (Chrysophyllum albidum) tissue fractionsunder ambient storage Vol. http://www.academicj. African Journal of Food Science, 13(10), 225-234.

Adeleye, S., Orji, C., Braide, W., and Akaluka, C. (2016). Phytochemistry and antimicrobial property of fruits of Chrysophyllum albidum against selected clinical isolates. International Letters of Natural Sciences. 55, 44-51.

Adeleye, S., Orji, C., Braide, W., and Akaluka, C. (2016). Phytochemistry and antimicrobial property of fruits of Chrysophyllum albidum against selected clinical isolates International Letters of Natural Sciences. 55, 44-51. doi:0.18052/www.scipress.com/

Adewusi, H. A. (1997). The African star apple Chrysophyllum albidum indigenous knowledge from Ibadan, Southwest Nigeria. In proceedings of a National workshop on the potentials of the star apple in Nigeria. In proceedings of a National workshop on the potentials of the star apple in Nigeria, (pp. 25-33).

Adisa, S. S., Garba, S. A., Iyagbo, O. A., and Iyamo, A. O. (2000). Vitamin C, protein and mineral contents of African star apple (Chrysopyllum albidum). 18th Annual conference of Nigerian Institute of Science Laboratory Technology, Ibadan, (pp. 141-146).

Ajayi, I. A., and Ifedi, E. N. (2015). Chemical and Preliminary Toxicological Evaluation of Chrysophyllum albidum Seed Flour in Dietary Formulation of Albino Rats. Journal of Environmental Science, Toxicology and Food Technology, 9(6), 59-67. Retrieved from www.iosrjournals.org

Akubor, P. I., Yusuf, D., and Obiegunam, J. E. (2013). Proximate composition and some functional properties of flour from the kernel of African star apple (Chrysophyllual albidum). International Journal of Agricultural Policy and Research, 1 (3), 062-066.
Aletor, V. A. (1993). Allelochemicals in plant foods and feeding stuffs: Nutritional, biochemical and physiopathological aspects in animal production. Veterinary and Human Toxicology, 35, 57-67.

Amaechi, N. (2009). Nutritive and Anti - Nutritive Evaluation of wonderful kola (Buccholzia coricea) seeds. Pakistan Journal of Nutrition, 8, 1120-1122.

Amusa, N. A., Ashaya, O. E., and Oladapo, M. O. (2005). Biodeterioration of the African star apple (Chrysophyllum albiddum) and the effect on its food value. African Journal of Biotechnology, 11(3), 56-59.

Anang, M. A., Oteng-Peprah, M., and Opoku-Boadu, K. (2019). Extraction and Characterisation of African Star Apple (Chrysophyllum albidum) Seed Oil and the Adsorptive Properties of the Fruit Shell in Ghana. Hindawi International Journal of Food Science, 8 https://doi.org/10.1155/2019/4959586

Ando, T. O., Aluyor, E. O., Egualeona, X., and Momoh, S. S. (2013). Extraction and characterization of Chrysophyllum albidum and Luffa cylindrica seed oils. Petroleum Technology Development Journal, 3, 1.

Antony, S. R., Smart, D. S., and Lee, C. R. (2011). Biodiesel production from jatropha oil and its characterization. Research Journal of Chemical Sciences, 1(1), 81-87.

Anwer, S., El-Badry., and Ali, S. S. ( 2015). Essential oils: a promising remedy against fungal and bacterial human Keratitis. Egyptian Journal of Botany.

Asaolu, M. (2003). Chemical composition and phytochemical screening of the seeds of Garcinia kola. Pakistan Journal of Science and industrial research, 46, 145-147.

Asare, I. K., Abenaa, A. O., Duah-Bissiw, D., Ofosu, D. O., and Darfour, B. (2015). Nutritional and phytochemical constituents of the African Star Apple (Chrysophyllum albidum g. Don) Annals. Food Science and Technology.

Bakre, L. G., and Akinsaya, K. (2019). Crosslinking of Chrysophyllum albidum gum with calcium chloride to enhance its physicochemical, compressional and tableting properties. Journal of Reearch in Pharmaceutical Pracrice,, 23(3), 415425. 
Bello, F. A., and Henry, A. A. (2015). Storage Effects and the Postharvest Quality of African Star Apple Fruits (Chrysophyllum africanum) Under Ambient Conditions. African Journal of Food Science and Technology, 6, 35-43.

Christopher, E. A., and Dosunmu, M. I. (2011). Chemical Evaluation of Proximate Composition, Ascorbic Acid and Anti-Nutrients Content of African Star Apple (Chrysophyllum afrcanum) Fruit. International Journal of Recent Research and Applied Studies, 9, 17-46.

Christopher, E. A., and Dosunmu, M. I. (2011). Chemical Evaluation of Proximate Composition, Ascorbic Acid and Anti-Nutrients Content of African Star Apple (Chrysophyllum afrcanum) Fruit. International Journal of Recent Research and Applied Studies, 9, 17-46.

Dah-Dovonon, J. Z. (2000). Rapport du Bénin. In Réseau " Espèces LigneusesAlimentaires ». Compte rendu de la première reunion du Réseau: 11-13Décembre 2000. In G. O. Eyog-Matig O (Ed.). (pp. 2-19). Ouagadougou, Burkina Faso: International Plant Genetic Resources Institute.

Edem, D. O., Eka, O. U., and Ifon, E. T. (1984). Chemical evaluation of the value of the fruit of African Star apple (Chrysophyllum albidum). Food Chem, 14, 303-311.

Ewansiha, C. I., Asia, I. O., Ekebafe, L. O., Jatto, O. E., and Okodugha, G. (2011). Proximate and Mineral Composition of Seed Shell Pericap of Chrysophyllum albidum. Pacific Joiurnal of Science and Technology, 12, 363-365.

Gill, L. (1988). Taxanomy of flowering plants. Onitsha: African Feb. Publishers

Gilman, E. F., Watson, D. G., Klein, R. W., Koeser, A. K., Hilbert, D. R., and McLean, D. C. (2018). Chrysophyllum oliviforme: Satinleaf1 Firat published in U.S. Department of Agriculture, UF/IFAS Extension Service, University of Florid. University of Florida, IFAS, Florida A and M University Cooperative Extension Program, and Boards of County Commissioners Cooperating., Department of Agriculture, UF/IFAS Extension Service .

Henry, F. A. (2015). Storage effects and the postharvest quality of African star apple fruits (Chrysophyllum africanum) under ambient conditions. African Journal of. Food Science. Technology., 6(1), 35- 43.

Ibrahim, H. O., Osilesi, O., Adebawo, O. O., Onajobi, F. D., and Karigidi, K. O. (2017). NutrientsCompositions and Phytochemical Contents of Edible Parts of Chrysophyllum albidum Fruit. Journal of Nutrition and Food Science, 7, 579. doi:10.4172/2155-9600.1000579

Idowu, T., Ogundaini, A. O., Adesanya, S. A., Onawunmi, G., Osungunna, M. O., Obuotor, E. M., and Abegaz, B. M. (2016). isolation and characterization of chemical constituents from Chrysophyllum albidum g. Don-holl. Stem-bark extracts and their antioxidant and anti. African Journal of Traditional Complementary Alternative Medicine, 13(5), 182-189

Iheanyichukwu, E., Caleb, N. J., Uche, O. I., Ezkwa, A. S., and Nkechinyere, E. A. (2017). Nutritional Properties and Antioxidant Activity of Chrysophyllum africanum Leaves and Pulp. Journal of Molecular Pharmaceutical Organization Process Research, 5, 139.

Iwu, M., Duncan, A., and Okunji, C. (1999). New Antimicrobials of plant origin. In J. (. Janick (Ed.). ASHS Press, Alexandria, V.A,.

Jayeoba, O. J., Ige, M. M., Omolaiye, J. A., Gbadamosi, S. O., Ogunbanjo, R. O., and Abiola, I. O. (2010). Chemical composition and physical properties of African star apple (Chrysophyllum albidum). ASSET: An International Journal , 7(1), 37-42.

Jimoh, F. O., and Oladiji, A. T. (2004). Preliminary studies of Piliostigma thonningii seeds: Proximate analysis, mineral composition and phytochemical screening. African Journal of Biotechnology, 4, 1439-1442.

Kuras, M., Pilarski, R., Nowakowska, J., Zobel, A., and Brzost, K. (2009). Effect of alkaloid-free and alkaloid-rich preparations from Uncaria tomentosa bark on mitotic activity and chromosome morphology evaluated by Allium test. Journal of Ethnopharmacology, 121, 140147.

Lawal, R. T., Eniola, K., Adepeju, A. B., F., O. S., and Oyeleke, G. (2016). Probiotic potential of lactic acid bacteria associated with african star apple (Chrysophyllum albidum). IJRDO-Journal of Agricultural and Research, 2(12). 
Madufor, C., Itodoh, U. E., Obidiegwu, M. U., and Nwakaudu, M. S. (2013). Chrysophyllum albidum (African Star Apple) Fruit Extract as Environmentally Friendly Inhibitor on the corrosion of Aluminum in acidic medium. Academic Research International, 4(2). Retrieved from www.journals.savap.org.pk

Manganaris, G. A., Goulas, V., Vicente, A. R., and Terry, L. A. (2014). Berry antioxidants: small fruits providing large benefits. J. Sci. Food. Agric. 94(5), 825-833.

Mbagwu, F. N., Iyama, C. N., and Ikpo, I. N. (2013). Comparative Petiole Chatateristics of C. Albidum, C. Cainito and C. Subnudum (Sapotaceae). Journal of Biology, Agriculture and Healthcare, 3(19)

Nwadinigwe, C. A. (1982). Nutritional value and mineral contents of Chrysophyllum albidum fruit. J. Sci. Foo. Agric. 33, 283-286.

Okigbo, B. (1978). Cropping systems and related research in Africa. Association for the advancement of Agricultural Science in Africa.

Okoye, E. I., and Ndiwe, I. (2016). Characterization of Chrysophyllum albidum and Anacardium occidentale gums as wet and dry binders in ciprofloxacin tablets. Marmara Pharmaceutical Journal, 20, 122-130.

Okwu, C., Osazuwa, E., and Igberaese, S. (2018). Nutritional and Chemical Composition of three Fruit Tastes of Chrysophyllum albidum (African Star Apple) in Nigeria. Inter. J. Adv. Res. Sci. Eng. Tech. 5(1)

Oladimeji, O. (2019). Influence of freezing and oven air drying on the total monomeric anthocyanins, vitamin c and antioxidant capacity of African star apple. Res. J. Food Sci. Nutr. 4(1), 22-31

Ologunagba, M. O., Azubuike, C. P., Silva, B. O., and Sadiku, O. R. (2017). Characterization of Chrysophyllum albidum Linn (family: Sapotaceae) endosperm seed gum for potential application as pharmaceutical excipient. Trop. J. Nat. Prod. Res. 1(5), 217-222

Olorunnisola, D. S. (2008). Anti-hyperglycemic and hypolipidemic effect of ethanolic extract of Chrysophyllum albidum seed cotyledon in alloxan induced-diabetic rats. Research Journal of Applied Sciences, 3, 123-127.

Oloyede, F. M., and Oloyede, F. A. (2014). The Antioxidant and Food value of Chrysophyllum albidum. Scholars J. Agric. Vet. Sci. 1, 1-5.

Omeje, K. O., Iroha, O. K., Edeke, A. A., Omeje, H. C., and Apeh, V. O. (2019). Characterization and fatty acid profile analysis of oil extracted from unexploited seed of African star apple (Udara). Oilseeds and fats, Crops and Lipids, 26(10)

Ominyi, C. E., Ominyi, C. J., and Nwali, U. (2016). Extraction, characterization and fatty acid profile of African star apple seed (Chrysophyllum albidum) oil. in Proceedings of the 17th World Congress on Oral Care and Probiotics.

Oputah, S. I., Mordi, R. C., Ajanaku, K. O., Olugbuyiro, J. A., Olorunshola, S. J., and Azuh, D. E. (2016). Phytochemical and Antibacterial Properties of Ethanolic Seed Extracts of Chrysophyllum albidum (African Star Apple). Oriental Journal of Physical Sciences. 1(1).

Orwa, C., Mutua, A., Kindt, R., Jamnadass, R., and Anthony, S. (2009). Agrofores tree Database: a tree reference and selection guide version.

Sayyar, S., Abidin, Z. Z., Yunus, R., and Muhammad, A. (2009). Extraction of oil from Jatropha seedsoptimization and kinetics. American Journal of Applied Science, 6, 145-152.

Ukana, D. A., Aniekan, E. A., and Godwin, N. E. (2012). Evaluation of proximate compositions and mineral elements in the star apple peel, pulp and seed. Journal of Basic and Applied Science. Research, 2. 4839-4843.

Umaru, M., Isah, A. G., Garba, M. U., and Zelihatu, U. (2015). Extraction of Chrysophyllum albidum seed oil: optimization and characterization. Chem. Proc. Eng. 30.

Ureigho, U. N. (2010). Nutrient Values of Chrysophyllum albidum Linn African Star Apple as a Domestic Income Plantation Species. African Research, 4, 50-56 